transfer credit, and attend a series of guest lectures given by leading political scientists. Additionally, attendees are given the chance to meet with recruiters from $\mathrm{Ph} . \mathrm{D}$. programs and representatives of Educational Testing Service. Many students who attend the Ralph Bunche Summer In- stitute excel in their senior year and enter graduate political science programs at top schools, often with full fellowships and teaching assistantships.

The institute is supported by the National Science Foundation, the University of Virginia, and APSA.

For more information about the

\section{Congressional Fellowship Program Contributors}

The Ameican Political Science Association extends its sincere thanks to contributors who continue to support the Congressional Fellowship Program, now in its 46th year. The individuals listed below are those who have contributed to the CFP's endowment over the past six months. A listing of contributors to other APSA Awards and Programs for the past quarter appears on the opposite page.
Anthony Anderson Paul E. Arnold

Michael A. Ashburn William I Bacchus Donald M. Bishop M. Kenneth Bowler Carol E. Buckland Richard B. Cheney Celia Cohen Joseph Cover Charles U. Daly David W. Davis Chris J. Deering joel H. Delofsky Francis J. Duggan Delmer Dunn Arlen I. Erdahl Elliott M. Feidler L. Boyd Finch Lisa Pullen Foust William E. Frenzel Jerry W. Friedheim Rulon R. Garfield Michael H. Garrety Robin Gaul Irwin N. Gertzog Esther Goldstein
Nelson P. Guild

Eugene Hayunga Karen Hein

Kim A. Hildred

Larry L. Hudson

Douglas johnson Mark Johnson

Edward Kelty John E. Kern Knut Kirste Bruce C. Ladd, Jr. Laureen Lazarovici Stephan Lesher Serge Logan Marvin R. Loewy Susan A. MacManus Susan McAndrew Roger McGuire Patrice Mitchell

Richard M. Moose

Roy D. Morey

Candice J. Nelson Cynthia T. Nickel Joseph R. Parker Leonard F. Parkinson Anne Marie Parsons Frank L. Prindle
James P. Rausch Peter F. Riehm Catherine E. Rudder Wilma Rule Joe Sanchez Jr. Patricia Saulsbery R. Stephen Scott Steven S. Smith Katherine Spring Mary Elizabeth Trotter

R. Lawrence Vandenberg Paul Vander Myde Thomas Vocino Richard D. Warden David M. Welborn Bonnie S. Whyte Curtis Wilkie Eddie N. Williams Thomas R. Wolanin Mark Wynn Judith Yalowitz Kazuo Yamauchi Barry Zalcman Diana D. Zentay Thomas Zittel
Ralph Bunche Summer Institute, contact Riqueza Feaster, Ralph Buche Summer Institute, American Political Science Association, 1527 New Hampshire Ave., NW, Washington, DC 20036-1206; Email: bunche@apsanet.org; www.apsanet. org/Minority/rbsi.html.

\section{CFP Continuing Seminar Series Set}

The Congressional Fellowship Program, with the generous support of the Congressional Research Service's Office of Scholarly Programs, is sponsoring an on-going seminar series for its Fellows and invited guests. The seminars are held every other week in the Jefferson Building of the Library of Congress.

Recent speakers included Adam Clymer, Washington Editor for The New York Times, who discussed the changing relationship between Congress and the media; Stanley Grimm, of the Legislative Counsel's Office in the House of Representatives, who described how legislation is drafted, with a focus on tax law; and Clyde Mark and Kenneth Katzman, CRS specialists in Middle East Affairs, who spoke about the Israeli/Palestinian conflict and U.S. policy on Iraq.

The series will run through July.

\section{APSA Establishes New Membership Category for Community College Faculty and High School AP Teachers}

The American Political Science Association has created a special membership category for community college faculty who teach courses in politics and government and high school teachers of AP government. If you are a community college or high school instructor, you can now join APSA for only $\$ 30$ a year.

Teachers who take advantage of this special membership offer will receive a subscription to $P S$ : Political Science and Politics, the quarterly professional journal that features articles on current political events and issues (many appropriate for class use) and "The Teacher," a spe- 